\title{
FINANCING RISKS OF MICRO, SMALL, AND MEDIUM ENTERPRISES (UMKM) WITH COOPERATION PATTERNS BETWEEN ISLAMIC BANK AND BAITUL MAAL WA TAMWIL (BMT) $)^{\Omega}$
}

\author{
Abd. Shomad, Trisadini Prasastinah Usanti and Prawitra Thalib \\ Faculty of Law Universitas Airlangga \\ E-mail: sishomad@yahoo.co.id
}

\begin{abstract}
Islamic Credit Unions and Baitul Maal Wa Tamwil (BMT) are part of Islamic micro finance as an effort of lower class society empowerment which is operated based on profit and loss sharing principle and implements Islamic moral values and group solidarity. This research discusses characteristics of cooperation patterns between Islamic bank and BMT in financing UMKM costumers and who would bear the financing risks of UMKM be. This research is doctrinal and applies both statute approach and con-ceptual approach. The result of this research shows that the characteristics of cooperation patterns between Islamic bank and BMT in financing UMKM costumers are identified by applying mudharabah muqayyadah contract between Islamic bank and Baitul Maal Wa Tamwil as shahibul maal while cus-tomers as mudharib. It is shahibul maal to bear risks as capital owner.
\end{abstract}

Keywords: financing, Islamic bank, baitul maal wa tamwil

\begin{abstract}
Abstrak
Koperasi Simpan Pinjam syariah dan Baitul Maal Wa Tamwil (BMT) merupakan bagian dari lembaga keuangan mikro syariah sebagai upaya pemberdayaan masyarakat lapisan bawah yang beroperasi berdasarkan prinsip pembagian hasil (termasuk berbagi kerugian) dan menggunakan nilai-nilai moral Islam dan solidaritas kelompok. Tulisan ini membahas tentang: karakteristik pola kerjasama antara bank syariah dengan BMT dalam pembiayaan pada nasabah UMKM dan siapa yang harus menanggung risiko pembiayaan UMKM pada pola kerjasama antara bank syariah dengan BMT. Penelitian ini bersifat doktrinal, dengan pendekatan peraturan perundang-undangan (statute approach) dan pendekatan konseptual (conceptual approach). Hasil penelitian menunjukan bahwa karakteristik pola kerjasama antara bank syariah dengan BMT dalam pembiayaan pada nasabah UMKM yaitu dengan menggunakan akad mudharabah muqayyadah antara bank syariah dan Baitul maal wa tamwil sebagai Shahibul maal dengan nasabah sebagai mudharib. Pihak yang harus menanggung risiko adalah shahibul maal selaku pemilik modal.
\end{abstract}

Kata kunci: pembiayaan, bank syariah, baitul maal wat tamwil

Introduction

Micro, Small, and Medium Enterprises (Indonesian: Usaha Mikro, Kecil, dan Menengah or UMKM) is important for Indonesian economy, ${ }^{1}$

$\Omega \quad$ This paper based on research by Dean Faculty of Law Universitas Airlangga decree Number 240/UN3.1.3/KD/ 2016 on April $12^{\text {th }} 2016$.

See more on Pradnya Paramita Hapsari, Abdul Hakim and Saleh Soeaidy, "Pengaruh Pertumbuhan Usaha Kecil Menengah (UKM) terhadap Pertumbuhan Ekonomi Daerah (Studi di Pemerintah Kota Batu)", Wacana, Vol. 17 No. 2, 2014, Depok: Faculty of Cultural Sciences, Universitas Indonesia, page 89; Djaimi Bakce, "Meningkatkan Peranan Usaha Kecil dan Menengah Melalui Rekonstruksi Strategi Industri”, Poelitik, Vol. 4 No. 1, 2008, Jakarta: Sekolah Pascasarjana Universitas Nasional, pages because UMKM has a positive characteristic as a sector which demands a large number of employees, accommodates the role of poor and dominant people in economic structure. Based on the recent data, the sector has a number of businesses reaching 51.3 million units or contribute up to $99 \%$, employment 90.9 million (97\%) contributing to GDP for Rp2.609 trillion (55.6\%), also contributing to foreign exchange

237-238; Teguh Sihono, "Usaha Kecil Menengah (UKM) dan Upaya Mengatasi Pengangguran”, Jurnal Economia, Vol. 1 No. 1, 2005, Yogyakarta: Faculty of Economics Universitas Negeri Yogyakarta, pages 77-78. 
amounting to Rp183, 8 trillion (20\%) (Bank Indonesia, 2010). ${ }^{2}$

For all this time, Micro, Small, and Medium Enterprises (UMKM) has shown a strategic role in expanding employment, increasing incomes and Indonesian economic growth; thus, the development should be supported. In doing so, national bank participation in terms of UMKM Credit granting or Financing should be encouraged in order to increase its segment or allocation.

Basically, Islamic bank is similar to conventional bank in which it can be either commercial bank or rural bank. Financial Service Authority (Indonesian: Otoritas Jasa Keuangan or OJK) supervises the activities of bank. As well as conventional bank, Islamic bank also serves as intermediary institution, ${ }^{3}$ which is responsible for collecting funds from people and redistribute them to those who need it in form of financing.

Islamic bank is obliged to provide financing to the UMKM businessmen either directly or indirectly through cooperation by executings, channeling and/or, joint financing. In the cooperation with Islamic rural bank; and/or other non-bank financial institutions, it refers to Bank Indonesia regulation concerning guidelines for arranging monthly report of commercial bank which is Credit Union, Baitul Maal Wa Tamwil. However, it is not free from risk which is potential loss due to the occurrence of certain event and one of which is financing risk. Financing risk is the failure of customers to meet their obligation to Islamic Rural Bank (BPRS) or non-bank financial institution according to the agree-

2 Mohammad Imsin Almustofa, “Usaha Mikro Dan Menengah Yang Didukung Lembaga Keuangan Dengan Pola Syariah Sebagai Modal Kegiatan Ekonomi Untuk Meningkatkan Daya Saing Daerah", Proseding Seminar Nasional Competitive Advantage, Vol. 1 No. 1, 20011, available on web: www.journal.unipdu.ac.id/index.php/seminas/ article/viewFile/10/11, accessed on February $20^{\text {th }}$, 2016.

3 See Syafii Antonio and Hilman F. Nugraha, "Peran Intermediasi Sosial Perbankan Syariah bagi Masyarakat Miskin”, Tsaqafah, Vol. 9 No. 1, April 2013, Ponorogo: Universitas Darussalam Gontor, page 146; Muslimin Kara, "Kontribusi Pembiayaan Perbankan Syariah Terhadap Pengembangan Usaha Kecil, Mikro dan Menengah", Ahkam, Vol. XIII No. 2, July 2013, Jakarta: Faculty of Shariah and Law of Universitas Islam Negeri Syarif Hidayatullah, page 315 . ment. As it is known that funds used in cooperation with BPRS/non-bank financial institution is derived from Islamic bank through its depositors and investors.

Islamic Credit Union and Baitul Maal Wa Tamwil (BMT) is part of Islamic Microfinance, as regulated in Law Number 1 Year 2013 on Microfinance. Islamic Microfinance in Indonesia has developed and become The Largest Islamic Microfinance in the world because Indonesia is a country which has the most varied Islamic Microfinance (Indonesian: Lembaga Keuangan Mikro Syariah or LKMS), the largest number of customers (especially BMT), the only one Microfinance which has Islamic Contract Guidelines in the world.

BMT is an empowerment effort of lower class society by Islamic community members. ${ }^{4}$ This microfinance organization usually operates based on profit and loss sharing principle and uses Islamic moral values and group solidarity as a social capital to support loan payment. Group solidarity is built through regular meetings and consultations. Sometimes BMT also runs retail businesses to support small business financing scheme. Some of financial products and services offered by BMT are similar to Islamic Banks and Islamic Rural Banks (BPRS) products. However, the distinctive characteristics lies on the customers: Islamic banks usually attract middleclass Muslim office workers while BPRS mostly serves lower and middle-class Muslims. There are some customer groups of Islamic banks/ BPRS which are also as the customers of BMT; however, most of BMT customers are Muslims who have small and medium enterprises which have relatively limited access to bank. Thus, BMT is a good supporter for Small and Medium Enterprises (UKM). Most of the business activities in Indonesia consist of small and medium enterprises. As a main support of real economic sector, BMT can develop well if it is supported by availability of adequate financial resources

\footnotetext{
Rokhmat Subagiyo, "Pengaruh Brand Image Terhadap Keputusan Nasabah Dalam Memilih Pembiayaan Di Bmt Sahara Tulungagung", Malia: Jurnal Ekonomi Islam, Vol. 8 No. 1, 2016, Pasuruan: Islam Economics Study Program of Universitas Yudharta, page 2.
} 
and in accordance with the values of justice and a good organization/Human Resources management. As Islamic microfinance, BMT should have improved itself to fulfill society needs for funds to develop business activities. BMT contributes to the success of development process; therefore, slow but sure, it can decrease the number of poor people in Indonesia. ${ }^{5}$

\section{Problem Statements}

Based on the background above, the problem statements are formulated as follows: first, what are the characteristics of cooperation pattern between Islamic bank and BMT in financing UMKM customers? and second, who should bear the financing risk of UMKM in cooperation pattern between Islamic bank and BMT?

\section{Research Method}

This study is a doctrinal research since law science is prescriptive rather than descriptive as well as natural sciences and social sciences. This study applied statute approach and conceptual approach. In Islamic banking, statute approach examines verses in the Quran, Hadits, and all laws and regulations correlated to legal issues. The studied law is Law Number 20 Year 2008 on Micro, Small and Medium Enterprises, Law Number 21 Year 2008 on Islamic Banking, Law Number 21 Year 2011 on Financial Services Authority (OJK), Law Number 1 Year 2013 on Microfinance, Burgerlijk Wetboek and other regulations governing banking especially Islamic banking and DSN-MUI's fatwa. Meanwhile, Conceptual Approach is done by studying perspectives and doctrines developed in law science, especially concerning Islamic banking law. Then, the result is analyzed qualitatively.

\section{Discussion}

Characteristics of cooperation patterns between Islamic bank and BMT in financing Mic-

Christina Tri Setyorini, et.all, "Pengaruh Komitmen Organisasi,Budaya organisasi, Dan Keterlibatan Kerja ter hadap Kinerja Karyawan Baitulmaal wat Tamwil (BMT)", Media Riset Akuntansi, Vol. 2 No. 1 February 2012, Jakarta: Faculty of Economics and Social Sciences of Universitas Bakrie, page 33 . ro, Small, and Medium Enterprises (UMKM) customers

The granting of financing of Micro, Small, and Medium Enterprises (UMKM) is indirectly done by Islamic bank with Islamic financial institution through cooperation with executing, channeling, and/or joint financing (syndication). ${ }^{6}$ It is possible that Islamic bank has cooperation with Islamic rural bank, Islamic Credit Union or Baitul Maal Wa Tamwil.

In Executing pattern, financing distribution of UMKM to UMKM debtor is done by particular financial institutions: Islamic Rural Bank (BPRS); and/or other non-bank financial institutions as mentioned in Bank Indonesia regulation which governs guidelines for arranging monthly report of commercial banks, namely Credit Union, Baitul Maal Wa Tamwil and other equivalent institutions. Those financial institutions are the parties who will bear the risk in case of default or breach of contract done by UMKM debtor.

Channeling pattern is financing distribution of UMKM to UMKM debtor through particular financial institutions, that are BPRS; or other non-bank financial institutions as mentioned in Bank Indonesia regulation which governs guidelines for arranging monthly report of comercial banks, namely Credit Union, BMT and other equivalent institutions. Those institutions do not authorize to cut off credit granting or UMKM financing. Islamic bank as the fund owner has the authority to give UMKM financing and bear the risk in case of default or breach of contract done by UMKM debtor. Meanwhile, the third system is joint financing (syndication). Joint financing is UMKM's financing distribution to UMKM debtor which is done jointly with Islamic bank and certain financial institutions that are: BPRS; and/or other non-bank financial institutions such as Credit Union, Baitul Maal Wa Tamwil and other equivalent institutions.

BMT in doing their business must follow the guidelines which are related to financial institution risk for its existence. The precaution-

\footnotetext{
Johan Arifin, "Hubungan Hukum Kemitraan Dalam Linkage Program Perbankan Syari'ah”, Economica, Vol. IV No. 2, November 2013, Padang: Economics Education Study Program of STKIP PGRI Sumatera Barat, page 44
} 
ary principle is one of the guidelines, in this case BMT must apply this principle to ensure the security of public funds that has been trusted to them, where this level of trust will indirectly affect the public's trust to BMT. Each financing distributed to customers by BMT cannot be separated from these stages, as well as giving credit process in conventional bank. There are 4 (four) stages: first, the stage prior to the granting of financing is decided by BMT, BMT takes into consideration the financing application from prospective customers of facility receiver, this stage is called as financing analysis stage. Second, the stage after financing has been decided by BMT, then turning the decision into financing agreement and also implementation of the binding of collateral for the given financing. This stage is called as documentation of financing. Third, the stage after financing agreement is signed by both parties and the documentation has been completed, the financing is used by customers until the time period has not expired yet. This stage is called as supervision and security financing stage. Fourth, the stage where financing becomes problematic, that is saving and billing stage. The first until the third stage are the preventive stages for BMT so that the financing will not be problematic, meanwhile the fourth stage is repressive stage in which the financing becomes problematic. ${ }^{7}$

In mudharabah financing, BMT will do supervising and training of the development of business project which is managed by customers more strictly because the profit that will be gained by BMT, is the one from profit sharing based on agreed ratio from the project managed by customers. Therefore, if the project is failed then BMT get the risks of losing fund that has been given to customers. Unless the failure is caused by the customers themselves, they have to be responsible for that.

Within the time period of financing, it is possible where there is a condition of main deviation in terms of payment which makes delay

Rizki Tri Anugrah Bhakti, “Pemberdayaan Umkm Melalui Pembiayaan Dengan Prinsip Bagi Hasil Oleh Lembaga Keuangan Syariah" Arena Hukum, Vol. 6 No. 1, April 2013 Malang: Faculty of Law of Universitas Brawijaya, page 129. in payment or a condition that requires juridical action in repayment or the possibility of potential loss. These conditions are called as problematic financing, the condition of degrading quality does not occur in sudden, but it always gives a "warning sign" or the causal factors in financing time. There are some factors that cause problematic financing, namely internal factor and external factor.

Internal factors (come from BMT party) are in the form of: first, lack of comprehension of customer's business; second, less evaluation of customer's finance; third, an error of financing facility setting (potentially to do side streaming); fourth, the calculation of working capital is not based on business project of customer; fifth, overly optimistic of sales projecttions; sixth, sales projections do not calculate business behavior and underestimate the aspects of competitor; seventh, aspects of warranties are not taken marketable aspect into account; eighth, weak supervision and monitoring; ninth, mental erosion: this condition is affected reciprocally between customer and BMT chairman so it makes the granting process of financing is not based on clean practice of financial institutions.

In the meantime, external factors (come from outside party) involve: first, trustworthy customers (dishonest in giving information and report about his or her activity); second, using side streaming of funds; third, inadequate managing customers so that BMT is lost in the business competitiveness; fourth, the project is relatively new; fifth, the project saturating; sixth, inability to solve the problem/lack of mastering the project; seventh, the death of key person; eighth, the dispute among management; ninth, natural disaster; and tenth, government policy: regulation on a product or economic sector or industry that can either positively or negatively affect the company that is related to those industries. ${ }^{8}$

Trisadini Prasastinah Usanti dan A. Shomad, 2008, Prinsip Keadilan dalam Transaksi Berdasarkan Bagi Hasil di Bank Syariah, Laporan Penelitian, DIPA BOPTN Tahun Anggaran 2014, Surabaya: Faculty of Law, Universitas Airlangga, pages. 101-103. 
Portion of UMKM Financing Risks of in Cooperation Patterns between Islamic Bank and BMT

Granting the financing to UMKM, every BMT definitely expects that the financing can run smoothly, in this case the customers obey what have been agreed in agreement and pay off before due date. However, there is still possibility in which customers experience difficulty to pay off the credit, as the result it indirectly causes loss for BMT and Islamic bank. In civil law, debtor must meet the achievement, so if debtor cannot meet the obligation as it has been approved in the agreement then the debtor is said to have committed a default. ${ }^{9}$ Similarly as what has been set in Compilation of Islamic Economic Law (Indonesian: Kompilasi Hukum Ekonomi Syariah or KHES) Article 36, there are four circumstances in which the debtor can be said that he or she has committed breach of contract: first, do not break what has been agreed; second, do what has been agreed but not as it is; third, do what has been agreed but late; or fourth, do what has been agreed as don'ts. If in doing the contract there is a party that breaches it, they can get sanctions according to Article 38 KHES: recompense, cancellation of contract, switchover the risks, pay fine and/or court costs.

The imposition of related property uses types of guarantee institution which is decided with the kind of thing determined as security objects. If it is moveable property, then KHES decides collateral institution (Rahn) in Article 373-408, while in BurgerlijkWetboek (BW/Civil Law (ode), if the collateral is moveable property then the guarantee institution decided by KHES is collateral institution regulated in Article 1150-1160 BW, whereas if the collateral object is immoveable then the type of guarantee institution that will be used is mortgage guarantee institution regulated in Article 1162-1232 BW, the guarantee out of $B W$ is Law Number 4 Year 1996 on security rights along assets which are related to land and Law Number 42 Year 1999 on Fiduciary Security. ${ }^{10}$

Ibid, page 108.

10 See more on Trisadini Prasastinah Usanti, "Subsequently Acquired Assets as Fiduciary Security on Bank Loans",
Based on funding re-evaluation, settlement through collateral will be done by $B M T$ if there is no business prospect of customer and/ or customer is not cooperative in resolving the financing. Collateral execution is adjusted to the collateral institution which burdens collateral objects, Rahn, collateral mortgage, security rights collateral, and fiduciary. In collateral mortgage, the execution has been regulated on Article 1178 BW. Moreover, in security rights collateral based on Article 20 of Law Number 4 Year 1996 on security rights about land along with objects related to land, if debtor breaches the appointment, there are three alternatives that could be done by BMT, they are: firstly, according to the rights of first security rights holder to sell the object of security rights as mentioned on Article 6; secondly, based on executorial title which is contained in security rights certificate as mentioned on Article 14 paragraph (2): Objects of security rights are sold through public auction based on the procedures arranged in legislation for receivable settlement of security rights holder by privilege from other creditors; thirdly, collateral object sales could be done privately as long as it reaches the highest price.

In fiduciary security, based on Article 29 of Law Number 42 Year 1999 on fiduciary, if debtor breaches, the collateral object could be executed through these procedures: executorial title enforcement, sell the property attached in fiduciary under control of the creditor in public auction, and private sales based on the consent.

Islamic principle which is related to securities based on surah Al-Baqarah verse 283: "And if you are on a journey and you do not find a scribe, then take a pledge with possession...". It was also narrated by Aisyah said The Messenger of Allah (the Prophet Muhammad) bought some food on credit from a Jew, and he gave him a shield of his as collateral (Rahn) (Narrated by al-Bukhaari, Muslim and Nasa'i). ${ }^{11}$

Jurnal Dinamika Hukum, Vol. 16 No. 2, May 2016, Purwokerto: Faculty of Law, Universitas Jenderal Soedirman, page 114.

11 Ibid, pages.112-113. 
Based on covenant in financing contract, if there is one of the parties that does not fulfill their obligation or there is dispute between both parties and the consent is not achieved through discussion; therefore, the settlement is taken over by National Sharia Arbitration Board (Indonesian: Badan Arbitrasi Syariah Nasional or BASYARNAS). In this case, BASYARNAS have several authorities: first, Resolving muamalah (civil) dispute which occurred in scope of trade, finance, industry, services and others in a fair and immediate manner according to Law and legislation is fully authorized by the disputants, and other parties who agrees in written form to hand over the settlement to BASYARNAS according its own procedures; second, giving the binding suggestion by request of the parties without any dispute regarding a contract.

The consent to resolve the dispute settlement to BASYARNAS is done by attaching arbitration clause in a written contract, or with private arbitration contract which is made and approved by all parties, either before or after dispute occurred. Islamic principle is included in surah Al-Hujarat verse 9:

"And if two parties or groups among the believers engage in fighting, then make peace between them both. But if one of them outrages against the other, then fight you against the one that outrages till it complies with the Command of Allah. Then if it complies [and ceases outrage], then make reconciliation between them justly, and be equitable. Indeed! Allah loves those who are equitable".

And surah An-Nisa verse 35:

"And if you fear dissension between the two, send an arbitrator from his people and an arbitrator from her people. If they both desire reconciliation, Allah will cause it between them. Indeed, Allah is ever Knowing and Acquainted [with all things]."12

Settlement through litigation will be done by BMT if customer has no good intention, which means not showing the intention to fulfill their obligations, while the customer still has

12 Ibid, pages. 113-115. another property which is not under BMT authority or hiding it intentionally or else have other sources to settle the bad credit. Since the Law Number 3 Year 2006 on Religious Courts has been legitimized, any dispute in field of muamalah could be settled by Religious Courts. The purpose of Religious Courts establishment is to examine, decide and resolve cases at the first level of marriage, inheritance, wills, grants, endowment, tithe, infaq, and Islamic economics among Muslims. The substantial amendment on Law Number 3 Year 2006 is expansion of the power or authority of Religious Courts which also covers disputes in the field of Islamic economics. It is also covered on Article 49 of Law Number 3 Year 2006. Islamic economics is the act or the business activities carried out under Islamic principle including Islamic banks, Islamic insurance, Islamic reinsurance, Islamic mutual funds, Islamic bonds and medium-term comercial paper, Islamic securities, Islamic finance, Islamic pawnshops, pension funds Islamic financial institutions, Islamic finance and Islamic microfinance institutions.

Prior to the Law Number 3 Year 2006 has been legitimized, disputes in Islamic economics could not be settled in Religious Courts because the authorities of Religious Courts had been restricted by the Law Number 7 Year 1989 which only examine, decide and resolve cases that involve marriage, inheritance, wills, grants, endowment, and alms. It means that the Religious Courts could not examine, decide and resolve matters beyond these six areas. Hence, if there is a dispute in field Islamic economics, the parties may settle in court (litigation path) or National Sharia Arbitration Board (non-litigation path). ${ }^{13}$ The authorities of Religious Courts on the Law Number 3 Year 2006 provide clarity and certainty to the people and the perpetrators of Islamic economics. On Article 49, is mentioned that "Religious Courts duty and authority are to examine, decide and resolve cases at the first level among people who are Muslims .... ". The

\footnotetext{
13 See more on Rahadiwasi Bintoro, "Restrictions on The Religious Judiciarys' Authority As A Result Of Judicial Power Conflict Rules", Jurnal Dinamika Hukum, Vol. 15 No. 2, May 2015, Purwokerto: Faculty of Law of Universitas Jenderal Soedirman, pages 210-113.
} 
word 'people are Muslim' was later described in the explanation of Article 49 as follows: "what is meant by 'among people who are Muslims' are included person or legal entity that the subject obey themselves voluntarily to the laws of Islam ..." Then, based explanations Article 49, made clear that non-Muslims can resolve disputes through Religious Courts as long as they obey voluntarily to the Islamic law. This article also emphasizes that Religious Courts has an authority to settle disputes 'legal entity' which based on Islamic principles. According to that provision, so every legal entity that carry out their business act based on Islamic principles could settle the dispute in Religion Courts. ${ }^{14}$

\section{Conclusion}

The characteristics of cooperation patterns between Islamic Bank and BMT in financing UMKM customers are by using mudharabah muqayyadah contract between Islamic bank and Baitul Maal Wa Tamwil as Shahibul maal with customers as mudharib. Therefore, in the implementation of its business, mudharib must comply with the restrictions determined by shahibul maal as a requirement in financing of mudharabah muqayyadah. Furthermore, as the capital owner, the Islamic bank and BMT should not interfere customers' business, rather, Islamic bank and BMT should supervise and provide guidance to customers as mudharib which manages fund of shahibul maal.

The party which should bear the risks of UMKM financing in the cooperation pattern between Islamic bank with BMT, when referring to the pillars and mudharabah then shahibul maal is the capital owner; however, in practice if there is financing problems, the first step which is taken between shahibul maal and mudharib is deliberation. If the dispute cannot be resolved amicably, then the parties make consent to settle it through BASYARNAS or Religious Courts. Moreover, if in the contract requires the securities, then it will be resolved through guarantee institution which is appropriate with collateral

14 Trisadini P. Usantidan A. Shomad, op.cit., pages 115117. object, Rahn/mortgage or fiduciary, or security rights.

\section{References}

Almustofa, Mohammad Imsin. "Usaha Mikro Dan Menengah Yang Didukung Lembaga Keuangan Dengan Pola Syariah Sebagai Modal Kegiatan Ekonomi Untuk Meningkatkan Daya Saing Daerah". Proseding Seminar Nasional Competitive Advantage. Vol. 1 No. 1. 20011. Available on web: www. journal.unipdu.ac.id/index.php/seminas/ article/viewFile/10/11. Accessed on February $20^{\text {th }}, 2016$.

Antonio, Syafii dan Hilman F. Nugraha. "Peran Intermediasi Sosial Perbankan Syariah bagi Masyarakat Miskin". Tsaqafah. Vol. 9 No. 1. April 2013. Ponorogo: Universitas Darussalam Gontor;

Arifin, Johan. "Hubungan Hukum Kemitraan Dalam Linkage Program Perbankan Syari'ah". Economica. Vol. IV No. 2. November 2013. Padang: Economics Education Study Program of STKIP PGRI Sumatera Barat;

Bakce, Djaimi. "Meningkatkan Peranan Usaha Kecil dan Menengah Melalui Rekonstruksi Strategi Industri". Poelitik. Vol. 4 No. 1. 2008. Jakarta: Sekolah Pascasarjana Universitas Nasional;

Bhakti, Rizki Tri Anugrah. "Pemberdayaan UMKM Melalui Pembiayaan Dengan Prinsip Bagi Hasil Oleh Lembaga Keuangan Syariah" Arena Hukum. Vol. 6 No. 1. April 2013. Malang: Faculty of Law, Universitas Bra-wijaya;

Bintoro, Rahadi Wasi. "Restrictions on The Religious Judiciarys' Authority As A Result Of Judicial Power Conflict Rules". Jurnal Dinamika Hukum. Vol. 15 No. 2. Mei 2015. Purwokerto: Faculty of Law Universitas Jenderal Soedirman;

Hapsari, Pradnya Paramita. Abdul Hakim dan Sa-leh Soeaidy. "Pengaruh Pertumbuhan Usa-ha Kecil Menengah (UKM) terhadap Per-tumbuhan Ekonomi Daerah (Studi di Pe-merintah Kota Batu)". Wacana. Vol. 17 No. 2. 2014. Depok: Faculty of Humanities of Universitas Indonesia;

Kara, Muslimin. "Kontribusi Pembiayaan Perbankan Syariah Terhadap Pengembangan Usaha Kecil. Mikro dan Menengah". Ahkam. Vol. XIII No. 2. Juli 2013. Jakarta: Faculty of Shariah and Law of Universitas Islam Negeri Syarif Hidayatullah; 
Setyorini, Christina Tri. et.all. "Pengaruh Komitmen Organisasi.Budayaorganisasi. Dan Keterlibatan Kerjaterhadap Kinerja Karyawan Baitulmaalwat Tamwil (BMT)". Media Riset Akuntansi. Vol. 2 No. 1. February 2012. Jakarta: Faculty of Economics and Social Sciences of Universitas Bakrie;

Sihono, Teguh. "Usaha Kecil Menengah (UKM) dan Upaya Mengatasi Pengangguran". Jurnal Economia. Vol. 1 No. 1. 2005. Yogyakarta: Faculty of Economics of Universitas Negeri Yogyakarta;

Subagiyo, Rokhmat. "Pengaruh Brand Image Terhadap Keputusan Nasabah Dalam Memilih Pembiayaan Di Bmt Sahara Tulungagung”. Malia: Jurnal Ekonomi Islam. Vol.
8 No. 1. 2016. Pasuruan: Islamic Economics Study Program of Universitas Yudharta;

Usanti, Trisadini Prasastinah dan A. Shomad. 2008. Prinsip Keadilan dalam Transaksi Berdasarkan Bagi Hasil di Bank Syariah. Laporan Penelitian. DIPA BOPTN Tahun Anggaran 2014. Surabaya: Faculty of Law of Universitas Airlangga;

Usanti, Trisadini Prasastinah. "Subsequently Acquired Assets as Fiduciary Security on Bank Loans". Jurnal Dinamika Hukum. Vol. 16 No. 2. Mei 2016. Purwokerto: Faculty of Law of Universitas Jenderal Soedirman. 